\title{
Gaya Kepemimpinan Kepala Desa Dalam Pengambilan Keputusan di Desa Bakun Kecamatan Loloda Kebupaten Halmahera Barat
}

\author{
${ }^{1)}$ Norlin Kotalaha, ${ }^{2)}$ Thelma Wawointana, ${ }^{3)}$ Jeane E Langkai \\ Universitas Negeri Manado \\ norlinkotalaha90@gmail.com ${ }^{1}$,thelmawawointana@unima.ac.id ${ }^{2}$, jeanelangkai@unima.ac.id ${ }^{3}$
}

\begin{abstract}
Abstrak - Penelitian ini bertujuan untuk menganalisis gaya kepemimpinan Kepala Desa dalam mengambil keputusan di desa Bakun Kecamatan Loloda Kabupaten Halmhera Barat. Adapun konsep yang digunakan adalah tentang kepemimpinan, fungsi kepemimpinan, gaya kepemimpinan dan pengambilan keputusan. Metode yang digunakan adalah kualitatif, dengan fokus pada Gaya kepemimpiana Kepala Desa dalam Pengamgambilan Keputusan di Desa Bakun kecamatan Loloda Kabupaten Halmahera Barat. Data wawancara diperoleh dari Kepala urusan Umum, Ketua Badan Pemberdayaan Desa, Tokoh Adat, Tokoh masyarakat.
\end{abstract} Dokumentasi, tentang struktur organisasi perangkat Desa Bakun, data tersebut dianalisis secara kualitatif deskriptif. Hasil penelitian menunjukkan bahwa gaya kepemimpinan kepala desa cenderung bergaya otoriter, belum mengkomunikasikan apa yang diharapkan dari mereka, cenderung belum mendukung, pemimpin bersifat ramah terhadap bawahannya, atau gaya kepemimpinan yang perlu memandang dan melaksanakan dalam dua dimensi yakni mengarahkan, beorintasi produk,dan berjuang pada gaya kepemimpinan otokratis dan mendukung berorintasi pada bahawan dan berjaung pada tipe kepemimpinan bebas kendali. Penelitian ini menyimpulkan bahwa gaya kepemimpinan kepala desa Bakun Kecamatan Halmahera Barat : a).belum berorientasi pada tugas sebagaimana yang ditetapkan dalam peraturan tentang kepala desa, b). belum mementingkan hubungan kerjasama, c). belum berorientasi pada bawahan. Untuk itu disarankan bahwa Kepala Desa Bakun dalam menjalankan tugas sebaiknya: a).berorientasi pada tugas sebagaimana yang ditetapkan dalam peraturan tentang kepala desa, b). mementingkan hubungan kerjasama, c). berorientasi pada bawahan.

Kata kunci: Gaya Kepemimpinan Kepala Desa, Halmahera Barat

\section{PENDAHULUAN}

Kepemimpinan adalah sebuah hubungan yang saling mempengaruhi di antara pemimpin dan pengikut (bawahan) yang menginginkan perubahan nyata yang mencerminkan tujuan bersamanya [1]. Dalam organisasi public kepemimpinan merupakan faktor penting dalam mempengaruhi perilaku bawahan untuk mencapai tujuan tertentu, 
seperti halnya kepala desa, berperan penting sebagai pemimpin di desa dan sebaiknya memiliki kemampuan untuk mengarahkan masyarkat untuk berpastisipasi dalam pembangunan [2]. Kepala desa adalah jabatan pemerintahan yang merupakan unsur pemerintah yang paling dekat dan berinteraksi dengan masyarakat dan diharapkan mengetahui permasalahan dan kebutuhan masyarakat. Kepala Desa bertugas menyelenggarakan

Pemerintahan,

Pembangunan, dan pemberdayaan masyarakat Desa [3].

$\begin{array}{rrr} & \text { Berdasarkan tugas } & \text { tersebut Kepala } \\ \text { desa } & \text { berwewenang } & \text { memimpin }\end{array}$
penyelenggaraan Pemerintahan. mengangkat dan memberhentikan perangkat Desa, memegang kekuasaan pengelolaan Keuangan dan Aset Desa, menetapkan Peraturan Desa, menetapkan Anggaran Pendapatan dan Belanja Desa, membina kehidupan masyarakat Desa, membina ketenteraman dan ketertiban masyarakat Desa, membina dan meningkatkan perekonomian Desa serta mengintegrasikannya agar mencapai perekonomian skala produktif untuk sebesarbesarnya kemakmuran masyarakat, mengembangkan kehidupan sosial budaya masyarakat, memanfaatkan teknologi tepat guna, mengoordinasikan Pembangunan secara partisipatif, mewakili Desa di dalam dan di luar pengadilan atau menunjuk kuasa hukum sesuai peraturan dan (o) melaksanakan wewenang lain sesuai peraturan .
Fenomena kepemimpinan Kepala Desa di Desa Bakun Kecamatan Loloda Selatan Kabupaten Halmahera Barat berdasar data historis sering diperhadapkan pada persoalan klasik, dimana hampir seluruh pengambilan keputusan, mengabaikan kekuatan informasi dan data analisis yang akurat, sehingga keputusan-keputusan yang diambil oleh epala desa berhadapan dengan tantangan yang sangat kristis dan sulit untuk diimplementasikan. Di samping itu kepala desa lebih banyak bekerja sendiri dan kurang menjalin hubungan kerja dengan bahwahannya. Oleh sebab itu hubungan kepala desa dengan bawahannya menjadi kurang harmonis dan akibatnya aparatur desa belum dapat bekerja secara efektf dan efesien. Tidak semua masyarakat dan bawahan memiliki persepsi yang sama sehubungan pengambilan keputusan kepada desa. Masyarakat pada dasarnya mendambahkan kepala desa memiliki kemampuan sesuai tugas dan wewenang yang diberikan oleh kebijakan kepadanya. Sebagai contoh kepala desa mengambil kebijakan sendiri untuk membuat pagar beton dan TPT (tembok penahan tanah) pada beberapa keluarga sementara yang diprogramkan belum dinikmati oleh masyarakat seperti: air bersih, jalan ekonomi dan jalan antara desa. Kepala desa dalam observasi dinilai kurang memberikan perhatian kepada masyarakat dalam hal ini kehadiran acara di desa seperti pesta pernikahan, kedukaan dan syukuran dan lebih banyak mewakilkan pada bawahannya, 
cenderung menjaga jarak dann hanya dekat dengan orang-orang tertentu dengan bawahanya seperti, Kaur, BPD, toko-toko masyarakat dan cenderung otoriter dan menuntut masyarakat mengikuti segala kehendaknya. Berdasarkan latar belakang mesalah tersebut maka dilakukan pengkajian secara teoritik dan metodologis dari dimensi gaya kepemimpinan.

Penelitian ini dilakukan dengan tujuan menganalisis gaya kepemimpinan Kepala Desa Bakun Kecamatan Loloda Kabupaten Halmhera Barat.

\section{METODE PENELITIAN}

Penelitian ini dilakukan dengan menggunakan pendekatan kualitatif [4], dengan fokus pada Gaya kepemimpiana Kepala Desa dalam Pengamgambilan Keputusan di Desa Bakun kecamatan Loloda Kabupaten Halmahera Barat. Data wawancara diperoleh dari Kaur Umum, Ketua BPD, Toko Adat, Toko masyarakat. Dokumentasi, tentang struktur organisasi perangkat Desa Bakun, Kecamatan Loloda Kabupaten Halmahera Barat dan observasi yaitu mengamati gaya kepemimpinan kepala desa. Ketiga data tersebut dianalisis secara deskriptif.

\section{HASIL DAN PEMBAHASAN}

\section{A. Hasil Penelitian dan Pembahasan}

a. Orientasi pada tugas

Wawancara pada 'DW' selaku Kaur Umum. Terkait dengan karakter Kepala Desa dalam pengambilan keputusan. Informan 'DW" menjawab: bahwa gaya kepemimpinan Kepala Desa Bakun jauh berbeda dengan pemimpinan yang sebelumnya, kenapa, karna di lihat dari karakter yang dimiliki beliau sehari-hari beliau terlalu tegas dalam mendelegasikan sesuatu pada bawahan dan disaat beliau memerintah bahawan terlalu keras dalam berkata-kata bahwa kadang mengeluarkan nada tingih yang sifatnya marah. Jika berbicara dalam pengambilan keputusanpun beliau sendiri yang memutuskannya.

Karakter dan pengambilan keputusan Kepala Desa dalam pelaksaan tugas? Informan ''FL', Menjawab bahwa Kepala Desa memang orangnya agak tegas dan keras, dalam setiap pengalambilan keputusan tidak pernah mendengarkan saran dan pendapat dari masyarakat, jika masyarakat bersikeras dengan suara terbanyak maka beliau dengan suara keras mengatakan bahwa siapa yang kepala desa, kebijakan hanya boleh diambil oleh saya sebagi pemimpin ( Wawancara Juni 2020). "YK" selaku ketua BPD, terkait gaya kepemimpinan Desa dalam orientasi kepada Tugasnya, diperoleh informasi bahwa Kepala Desa Bakun ini karakternya sangat keras dan tegas dalam menjalankan tugasnya, yang saya lihat bahwa dalam melakukan tugas sesuai dengan kemauan atau aturan dibuat sendiri sehingga menimbulkan kekecewaan pada masyarakat, sifat beliau yang selalu marahmarah dalam melaksanakan tugas terutama 
dalam pengambilan keputusannya, tidak ada yang berani mengkriktik beliau.'’( Wawalancara Juni 2020). MK" mengatakan bahwa: Sesuai keputusan kepala desa yang sudah disampaikan dan selalu diingatkan harus dilakukan dengan tuntas semua tugas-tugas sesuai aturan yang dibuat oleh pemimpin yaitu: Tugas Pokok dan fungsi pada bidang pemerintahan didesa, dalam ketegasannya adalah bagian dari orientasinya sebagai kepala desa dalam menjalankan tugas didesa, kengambilan keputusan yang diangap baik oleh beliau itu yang di kerjakan bawahannya.( Wawancara Juni 2020)

DW selaku kaur menjawab bahwa tugas pokok dan fungsi kepala desa selalu mengingatkan kepada kita sebgai bahawan bahwa harus melaksanakan tugas dengan baik dan bertanggung jawab, dan lam pengambilan keputusan beliau selalu bepegang pada peratuaran yang dibuatnya (Wawancara Juni 2020). "YK" menginformasikan bahwa Cara kepala desa dalam melestarikan tugas kepala bawahan, Kaur-kaur dan BPD beliau menggunakan bahasa yang sopan. Yang saya alami kepala desa biasa melestarikan tugas dengan raut muka yang kurang senyum (Wawancara Juni 2020). Dari informasi tersebut maka dapat dikatakan bahwa kepala desa tidak memiliki gaya kepemimpinan yang baik, belum berorientasi pada tugasnya, dalam hal ini komunikaksi yang kurang kepada hawahan yang menyebabkan efesiensi kerja tidaklah maksimal. Kepala desa belum memiliki target untuk waktu penyelesaian dan tidak melibatkan masyarakat dlam pekerjaan, melaksanakan tugas belum sesuai tugas pokok dan fungsi, kurang berkomunikasi dengan bawahan

\section{b. Mementingkan Hubungan Kerjasama 'DW' sebagai Kaur Umum Desa} Bakun menjawab bahwa: Hubungan kerja kepala desa tidak terlalu baik dengan bawahan begitu juga dengan pola kerja, dengan sifat keras yang dimiliki pemimpin terbawa kepada masyarakat dan kuarng memberikan pembinaan mengenai ketentraman, ketertiban dan ketekunan.( Wawancara Juni 2020). Ketua BPD "YK" menjawab bahwa bila bawahan melakukan kesalahan dalam tugas dengan spontannya beliau memarahi, ( Wawancara Juni 2020) dan FL mengatakan bahwa: beliau selalu memakai pola garis atasan dan bahwahan, sehingga dalam memberikan pembinaan sangatlah tegas tetapi selalu tidak pada sasarannya (Wawancara juni 2020). Veithzal Rivai tentang pola dasar gaya kepemimpian dengan mementingkan hasil yang akan dicapai dalam pengambilan keputusan. Akan tetapi dalam pengambilan keputusan berkaitan lansung dengan masyarakat, tentunya sebagai pelayanan masyarakat kepala desa harus mendengar keluhan dari masyaraka. Jadi dapat dijelaskan hahwa kepala desa tidak mementingkan kepentingan publik/masyarakat. Veithzal Rivai 
tentang pola dasar gaya kepemimpian dengan mementingkan hasil yang akan dicapai dalam pengambilan keputusan. Akan tetapi dalam pengambilan keputusan berkaitan lansung dengan masyarakat, tentunya sebagai pelayana masyarakat kepala desa harus mendengar keluhan dari masyarakat.

c. Orientasi Pada Bawahannya DW mengatakan bahwa kepala desa dengan sifat pribadi/masalah keluarga, yang saya lihat kepala desa ada perhatian kepada bawahan kadang beliau menayakan langsung dan kadang beliau lewat bawahannya.( Wawancara Juni 2020). YK menginformasikan bahwa Kepala desa dalam menjalankan tugas, beliau juga memperhatikan bawahannya yang mengalami dalam masalah keluarga/rumah tangga ( Wawancara juni 2020)

Gaya kepemimpinan yang efektif dibutuhkan pemimpin yang dapat meningkatan kinerja semua bawahan dalam mencapai tujuan organisasi yang dipimpinya sebagai instansi publik. Dengan demikian, gaya kepemimpinan dapat menjadi pedoman baik dalam peningkatan kerja bawahan yang dipimpin. Peranan kepemimpinana akan menjadi lebih penting dan sangat dibutuhkan untuk menyelaraskan berbagai macam kebutuhan, juga dapat menciptakan situasi kerja yang konsdusif. Di samping itu dapat mendorong para bahawan untuk berperilaku baik sesuai tujuan organisasi yang ditetapkan. Dari berbagai cara yang dilakukan oleh pemimpin dalam menggerakan bahwahannya untuk mencapai tujuan organisasinya dan pada akhirnya harus dapat pula menimbulkan kinerja dari para bawahannya. Bahkan secara tidak langsung kepemimpinanan ikut menetukkan terbentuknya kinerja dari pegawai. Semakin baik kepemimpinan sesorangg maka semakin baik pula kinrja bawahannya.

Dalam rangka mewujudkan pemerintah yang baik serta mewujudkan kesejateraan masyarakat maka tujuan nasional diperlalkukan peran serta dari aparatur pemerintah pusat, daerah sampai ke Desa. Salah satu tantangan besar yang dihadapi oleh pemerintah khususnya pemrintah daerah, bagaimana menampilkan aparatur yang fungsinya untuk memenuhi aspirasi dari masyarakat setempat. Aparat pemerintah berperan sangatlah penting karena terlaksanannya roda pemerintahan baik pelayanan kepada masyarakat,dibutuhkan sikap profesional dari setiap aparatur baik pemimpin maupun bawahan. Sikap profesisonal melekat pada setiap aparatur pemerintah tentunya akan dpata meningkatkan produktivitas kerja dan akan terwujudnya kesejateraan masyarakat lewat pelayanan publik yang baik.

Kepemimpinan merupakan salah satu unsur keberhasilan dari organisasi, terlebih membawa sebuah perubahan. Dengan memahami apa yang dimaksud arti 
kepemimpinan. Hal ini disebabkan karena kepemimpinan dilakukan oleh seorang pemimpin dan pemimpinmembantu tugas untuk melaksanakan kepemimpinan tersebut.

kepemimpinan adalah suatu proses saling mendorong melaui keberhasilan interaksi dari perbedaan-perbedaan individu, mengontrol daya manusia dalam mengejar tujuan bersama.Sedangkan konsep kepemimpinan neburut Kartono.(1998:25) mengemukakan habwa kepemimpinan sebagai proses pengarahan dan memepengaruhi aktivitas yang berkaitan dengan tugas dari para anggota kelompok.

Kepemimpinan mempunyai peranan utama dalam pengendalian, mengarahkan, membimbing dan membawa orang-orang yang dipimpinnya menuju ke tujuan yang diinginkan oleh pemimpin. Dapat disimpulkan hahwa keberhasilan pempimpin membawa organisasinya ke tujuan yang diinginkan oleh pemimpin tersebut

Gaya kepemimpinan kepala desa perlu: Mengarahkan, sama dengan gaya otoriter, bawahan mengetahui apa yang diharapkan dari mereka, mendukung, pemimpin bersifat ramah terhadap bawahannya, beorintasi pada tuga, pemimpin menyusun sarangkaian tujuan menantang untuk bawahannya atau dapat dikatakan gaya kepemimpinan perlu memandang dan melaksanakan dalam dua dimensi yakni mengarahkan, beorintasi produk,dan berjuang pada gaya kepemimpinan otokratis dan mendukung berorintasi pada bahawan dan berjaung pada tipe kepemimpinan bebas kendali [5]

\section{KESIMPULAN}

Berdasarkan hasil analisis data pada bab sebelumnya maka disimpulkan bahwa gaya kepemimpinan kepala desa Bakun : a).belum berorientasi pada tugas sebagaimana yang ditetapkan dalam peraturan tentang kepala desa, b). belum mementingkan hubungan kerjasama, c). belum berorientasi pada bawahan.

Untuk itu disarankan bahwa Kepala Desa Bakun dalam menjalankan tugas sebaiknya: a).berorientasi pada tugas sebagaimana yang ditetapkan dalam peraturan tentang kepala desa, b). mementingkan hubungan kerjasama, c). berorientasi pada bawahan.

\section{DAFTAR PUSTAKA}

[1] Rivai, Veithzal. (2004). Kepemimpinan dan Perilaku Organisasi. Edisi Kedua. Jakarta: PT. Raja Grafindo Persada.

[2] Djatmiko, Yayat Hayati. 2008 Perilaku Oranisasi Bandung.Alfabeta

[3] Keating, Charles J. 1986. Kepemimpinan: dan Pengembangannya (terjemahan).

[4] Moleong, Lexi J. 2007. Metodologi Penelitian Kualitatif Edisi Revisi, PT. Remaja Rosdakarya, Bandung 
Jurnal Kajian Kebijakan dan IImu Administrasi Negara (JURNAL ADMINISTRO) Vol 2 No. 22020 P ISSN: 2714 - 6413 E ISSN: $2714-6421$ http://ejournal.unima.ac.id/index.php/administro

[5] Jakarta: PT Raja Grafindo Parsada. Kouzes \& Posner, 2004. Leadership the Challenge. Tantangan Kepemimpinan Edisi 3, Erlangga, Jakarta. 